\title{
The birth and development of Vocational Education Teachers' (VET) professional identity
}

Koski-Heikkinen, Anne

Kainuu Vocational College, Finland (anne.koski-heikkinen@kao.fi)

Määttä, Kaarina

University of Lapland, Finland (Kaarina.Maatta@ulapland.fi)

Uusiautti, Satu $\bigotimes$

University of Lapland, Finland (satu@uusiautti.fi)

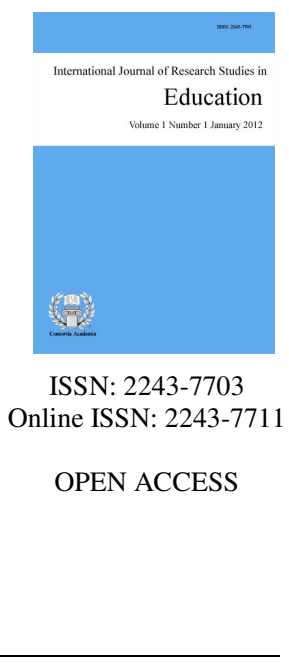

\section{Abstract}

The purpose of this study was to analyze how VETs construct their identities in their career-related narratives. This was studied through three research questions: (1) How does professional identity manifest itself when described by VETs? (2) How does one end up in a VET's career and how is this career decision related to the development of professional identity? and (3) How do VETs perceive the future of professional identity? The narrative method was chosen because it suits extremely well to research on teachers' professional development and identity construction: Teachers create and construct their identities by talking, interpreting, and reflecting their experiences and opinions. In this study, Finnish VETs $(\mathrm{N}=12)$ were recruited from one vocational education college with multiple fields. The narrative data obtained from them included oral $(n=5)$ and written $(n=7)$ narratives. The narratives were categorized with the analysis of narratives and combined as conclusions with the narrative analysis. The VET's narratives included four main themes defining their professional identities: substance knowledge, pedagogical expertise, work-life skills, and developmental abilities. Based on the data, two main ways of ending up in a VET's career could be distinguished. As a whole, a VET's identity appeared complex and dynamic. The development of a VET's professional identity was viewed from four basic perspectives. Suggestions for vocational teacher education are given in the light of the findings of this study.

Keywords: professional identity; vocational education teacher; narrative research; vocational education; identity development 


\section{The birth and development of Vocational Education Teachers' (VET) professional identity}

\section{Introduction}

Vocational education and the work of vocational education teachers (VET) have faced many challenges in Finland and abroad. The explosion of information, internationalization, and technological development (e.g., Green, 1999) as well as national development (e.g., Alam, 2008) required renewal of education. Today's occupations are replaced by new ones. In Finland, the task of vocational education is to provide students with the theoretical and practical basic readiness to work in professions but also to educate students into life-long learners. One has to be able to update vocational skills constantly (Aalto, Ahokas, \& Kuosa, 2008; Ministry of Education and Culture, 2010).

The requirements for change in professions and vocational education reflect on VET's daily work (e.g., Antikainen, 2006; Tennant \& Yates, 2005; Vähäsantanen, 2013). This is a universal phenomenon. VET's job description is wide: they should be good co-workers, have wide networks in education and worklife, support and guide learning processes, encounter and support diverse students, and develop their professional field (see also McDiarmid \& Clevenger-Bright, 2008; Ministry of Education and Culture, 2010). The group of vocational education students is quite a heterogeneous one, which also sets unique demands on VET's work.

In all, the changing times create pressures to VET's professional knowledge and identity. After reviewing a study of VET's professional identity, we noted how research on the development of professional identity has focused on especially class teachers, while research on VETs has been minimal (see Köpsén, 2014). In sum, educational research on VETs has been scarce in general.

This study analyzes how Finnish VETs describe their work today and related changes in their profession. Their narratives show how they have ended up as VETs, how they have developed and renewed during their careers. When describing their work, VETs also happen to describe the birth and development of their professional identities. This study is based on the first author's PhD research data (Koski-Heikkinen, 2014).

\section{Theoretical Review}

\subsection{The Concept of Identity}

The concept of identity has been analyzed and defined in various fields of research and in many ways. The essence of identity has been studied by respected theorists, among others, Zygmunt Bauman (1992), Pierre Bourdieu (1980), Anthony Giddens (1991), Jürgen Habermas (1991), Stuart Hall (1996), Paul Ricoeur (1992), and Margaret Somers (1994). Carol Rodgers and Katherine Scott (2008) sum up the basic elements of identity as follows (see also Beauchamp \& Thomas, 2009, 2011; Beijaard, Meijer, \& Verloop, 2004; Little \& Bartlett, 2002; Urzua \& Vasquez, 2008):

$>$ The construction of identity is always connected with the social, cultural, political, and historical development and environment.

$>\quad$ Identity is formed within social relationships with the contribution of emotions.

$>$ Identity changes according to situation.

$>$ Identity is re-constructed through narratives. 
The concept of identity is also used for illustrating the dimension of human being's existence and consciousness. From this perspective, identity describes a human being's understanding one himself or herself and his or her belonging to the surrounding cultural community. Due to the constantly changing society, Stuart Hall (1996) regards today's conception of identity as the celebration of many worlds that is formed and molded constantly in relation to the cultural organizations in our environment. An individual person tries to construct a stable identity and looks for one when does not yet possess one (Côte, 1996).

Douwe Beijaard, Paulien Meijer, and Nico Verloop (2004) define identity as a series of events in continuing movement that changes and transforms according to the current life situation (see also Flores \& Day, 2006). The concept of identity include a human being's understanding and experience of the continuity of his or her existence and how he or she consciously perceives his or her stability and gradual change (see also Day, Kington, Stobart, \& Sammons, 2006). Catherine Beauchamp and Lynn Thomas $(2009,2011)$ have noted that identities change across situations and environments as well as eras. Identity is constructed in historical and social contexts and in relation to other people (Brubaker \& Cooper, 2000).

\subsection{A teacher's professional identity}

The structure and birth of teachers' professional identity have been widely studied (Bullough, 2005; Flores \& Day, 2006; Thomas \& Beauchamp, 2011). Research has been often focused on how to become a good teacher. Good teacherhood and good professional identity cover many factors that cannot be easily described comprehensively (e.g., Sachs, 2001). Professional identity develops and changes along age and life situations. Despite all changes, human beings also experience stability of identity because one's self does include something same, personal, and deeply-rooted (e.g., Beijaard et al., 2004; Day et al., 2006; Flores \& Day, 2006).

Various phases of the development of teachers' identity have been recognized by research. Ji Hong (2010) found six factors defining teachers' professional identity: value, self-efficacy, commitment, emotions, knowledge and beliefs, and micro-politics. Beijaard, Meijer, and Verloop (2004) created a glance at teachers' professional identity by reviewing 22 related studies. According to their findings, teachers' professional identity is an ongoing process necessitating interpretation and re-interpretation of experiences. Based on them, teachers try to answer not only the question "Who am I at this moment?" but also "Who do I want to become?" In addition, personal and context-bound factors influence teachers' professional identity. Personal identities develop continuously and, indeed, the identity construction is a life-long project (Kelctermans, 1993). Collective and context-bound identity is an outcome of social interaction. Therefore, the work unit and profession, in which one is working, molds one's identity to some extent (see e.g., Ricoeur, 1992; Ricoeur \& Valdés, 1991).

Likewise, Rodgers and Scott (2008) specify that teachers' professional identity and identity development are connected with teachers' work environments. To construct a proper professional identity, a teacher has to be able to align his or her own thoughts and values with his or her work environment. This requires reflection of one's own values (see also Beauchamp \& Thomas, 2011; Beijaard et al., 2004; Vähäsantanen, 2013). Teacher education and first-year teaching experiences label and direct the construction of professional identity (Uusiautti \& Määttä, 2013a).

\subsection{Teacherhood as Narrative Identity}

Identities change and develop constantly (e.g., Coldron \& Smith, 1999), and so do teachers' professional identity. Identity is never ready. The concept of narrative identity can help illustrating some of the theoretical principles of professional identity construction (Day et al., 2006). Narrative identity refers to identity construction via narratives and self-expressions. When a teacher answers the question of "Who am I as a teacher and what do I want to accomplish in this work?" the teacher reflects his or her becoming as a teacher, teaching work, and the profound essence of his or her profession (Thomas \& Beauchamp, 2011).

Anna Sfard and Anna Prusak (2005) defined identity construction through various self-expressions. With 
Koski-Heikkinen, A., Määttä, K., \& Uusiautti, S.

this they refer to all life stories and narratives people tell to themselves and to others. However, what one tells about oneself as a truth does not necessarily appear truthful to others. Sfard and Prusak (2005) distinguish three parties, "narrators", that are significant to a person's identity: The first-person identity refers to one inner narrative about oneself. The second-person identity covers the narrative of oneself to another, while the third-person identity refers to a narrative about another person told to a third party. The first-person narrative is most likely to reveal a person's true identity conception.

According to Raija Erkkilä (2005), narrative identity emphasizes the interaction between a human being and his or her environment, and this is why one has a chance to change the narrative about one's identity. Similarly, Sanne Akkerman and Paulien Meijer (2011) noted that teachers' identity is based on reflective self-understanding (see also Rodgers \& Scott, 2008). The depth of self-reflection and the social and societal environment function as the mirrors of teachers' professional identity.

Stuart Hall (1996) stated that identities well when the selves are changed into narratives. He continues that this process, although fictive in nature, does not cut the ground from under the feet of its discursive, material, or political influences. According to Hall (1996), identities are constructed within the discourse, not outside of it. What follows is that identities have to be analyzed in certain, specific historical and institutional place, within certain specific discursive constructions and practices, and produced by using certain statement strategies (Hall, 1996; see also Rodgers \& Scott, 2008; Trent, 2013). According to Paul Ricoeur (1992), narrative is the primary way of interpreting oneself, in other words, to form an identity about one's personality (see also Ricoeur \& Valdés, 1991; Sfard \& Prusak, 2005).

\section{Method}

\subsection{Research Questions}

The purpose of this study was to analyze how VETs construct their identities in their career-related narratives and how do their professional identities appear in their descriptions of their daily work as VETs? The following research questions were set for this study:

1. How does professional identity manifest itself when described by VETs?

2. How does one end up in a VET's career and how is this career decision related to the development of professional identity?

3. How do VETs perceive the future of professional identity?

When talking about their work, VETs also reveal their life stories. Autobiographies form a salient part of the birth and development of professional identities and conception of who they are as teachers and what they want to accomplish in their profession.

\subsection{Narrative Research Approach}

Narrative research literature has increased abundantly during the past decade (e.g., Bamberg, 2007; Clandinin, 2007; Gubrium \& Holstein, 2009; McAdams, Josselson, \& Lieblich, 2006). Kohler Riessman (2008) considers narrativity as all production and interpretation of fictive texts in narrative forms (see also Bell, 2009; Chase, 2010). Amos Hatch and Richard Wisniewski (1995) regard the context-bound, personal, and subjective nature of the narrative research method as its strength. However, they also highlight the role of power in such research approach: in narrative research, the power is given from the researcher to the research participant.

The narrative research approach simply refers to analysis of narratives told by people: "A simple definition of narrative approaches is: an analysis of the stories that people tell" (Gartner, 2007, p. 613). The narrative 
research approach belongs to the field of qualitative research and has become more and more popular since the 1990s, for example, in social sciences and especially in the science of education (see Spector-Mersel, 2011).

The concept of narrative defines narrative analysis. One of the most famous narrative analyzing methods is based on Donald Polkinghorne's (1995) way of distinguishing the analysis of narratives from the narrative analysis. The analysis of narratives means that situations and events, people's characteristics and other elements in narratives are categorized into themes and types. The narrative analysis pursues constructing a new narrative that is based on the original narrative data (see also Bruner, 1986). According to Polkinghorne (1995), a result of the narrative analysis is a time-bound, structured, and plotted entity with a conclusion. This kind of meta-narrative reveals various parts of the data and their confluences. The narrative method suits extremely well to research on teachers' professional development and identity construction: teachers create and construct their identities by talking, interpreting, and reflecting their experiences and opinions (Connelly \& Clandinin, 1999; Somers, 1994).

\subsection{Research Participants and Data}

In this study, twelve Finnish VETs were recruited from one vocational education college with multiple fields. The narrative data obtained from them included oral $(\mathrm{N}=5)$ and written $(\mathrm{N}=7)$ narratives. According to Ricoeur (1992), they are equally original because writing has similar features than speech, but writing does not disappear like speech does. The methodological grounds for data analysis were based on the qualitative data, twelve narratives that were categorized with the analysis of narratives and combined as conclusions with the narrative analysis (cf., Uusiautti, 2008). The analysis of narratives means categorizing based on types, metaphors, or classes (Leavy, McSorley, \& Boté, 2007). Marjatta Saarnivaara (1998) notes that in narrative research description can be seen as the foundation of the construction of narratives. Description can be widened and specified with analysis. In this study, categorization followed the idea of the analysis of narratives pursuing the identification of key factors and their interconnectedness (see also Uusiautti, 2008). According to Jerome Bruner (1987), paradigmatic knowledge is typically rigorous and formal, and produces argumentation that follows from logical statements and careful definition of concepts and categories.

\subsection{Reliability and Limitations of the Research}

In narrative research like this one, the reliability and validity of the data are worth discussing. Transferability criterion refers to sufficient detail of the context and whether the findings can justifiably be applied to the other setting (Shenton, 2004). In this study, VETs presented various occupational fields and therefore, their descriptions of professional identity covered vocational education teacherhood widely. The meeting of the dependability criterion is difficult in qualitative work in general because the research themes and data are often impossible to repeat (Shenton, 2004). Careful description of the select methods and data obtained strengthen the dependability and trustworthiness of the study (Shenton, 2004). Naturally, other methods could have been applied as well, such as traditional themed interviews or questionnaires, but in this study, the narrative approach was selected based on its suitability to study individuals' perceptions of their own lives and development (see e.g., Hatch \& Wisniewski, 1995; Ricoeur, 1992).

Finally, to achieve confirmability, it is important to demonstrate that findings that emerge from the data and are not based on or influenced by researchers' own opinions or prejudices (Shenton, 2004). In this study, VETs described their careers openly, and the data obtained were abundant. However, the researcher who collected data was a VET herself. Therefore, critical reflection of her influence on the data analyses and interpretations was necessary, and the researcher collaboration through which this article was also created as well partly ensured the trustworthiness and critical evaluation of research. On the other hand, as the results showed, the VET's professional identity is complex. Without any familiarity with the profession, it might have been difficult to understand the special nature of the development of professional identity in VETs. 


\section{Results}

\subsection{The Elements of VET's professional identity}

The VET's narratives included four main themes defining their professional identities (cf. also, McDiarmid \& Clevenger-Bright, 2008).

Theme 1: Substance knowledge, including the know-how of VET's professional field, professional expertise, and work-specific skills.

Teachers are traditionally perceived as subject matter experts. Knowledge of subject matter has always been the core feature of a good teacher (Hoyle \& John, 1995). However, instead of distribution of information, todays' teachers are merely expected to handle transmission of knowledge. Moreover, evaluation of information and skills is important in these days. In addition, professional expertise has to be updated constantly, and the readiness to professional change and development has to be provided already in vocational basic education.

Theme 2: Pedagogical expertise, including the ability to lead teaching, learning, and study processes, organize and analyze teaching situations, and encounter and guide students.

Although technology and teaching methods develop all the time, teachers' personal inputs still matter. It is especially apparent in the pedagogical, ethical, and moral dimensions of teaching. Pedagogical expertise is a combination of many knowledge and skills related to student interaction and how they are applied in the practical complexity of teaching situations (Uusiautti \& Määttä, 2013b).

Theme 3: Work-life skills, including co-operation skills, willingness to create networks, ability to work in various teams, and economic and administration skills.

VETs work in collaboration with colleagues in the college and with employers and other representatives of the professional field. VETs function as mediators between vocational education students and work-life professionals.

Theme 4: Developmental abilities, ability and will to develop one's mastery over the knowledge and skills in one's vocational field, participate in the development of one's field and worklife, and trust in the progress of vocational development through teaching and learning processes.

Due to the professional change and variation, VETs are required to possess such knowledge and teaching skills that help vocational education students adjust to the day's professional expectations. VETs are expected to work for and influence the appreciation of their vocational field.

These four dimensions are next illustrated through narratives about how the teachers in this study became VETs. Their careers started differently and their professional identities had different emphases based on how they ended up in this career. The metaphor of a path was chosen to illustrate how VETs found their careers. Metaphors can be defined as ways of illustrating the meaning of another concept or bringing new viewpoints to the description of another concept (Beauchamp \& Thomas, 2011; Inkson \& Amundson, 2002; Thomas \& Beauchamp, 2011; see also Uusiautti, 2008). According to Satu Uusiautti (2008), metaphors can be seen as narrative instruments that can turn random, diversified, and vague concepts into consciously constructed and well-defined. The metaphor of path is here used for illustrating ups and downs, the positive and negative, in narratives contributing to the birth and development of VET's professional identity.

\subsection{VET career paths}

Based on the data, two main ways of ending up in a VET's career could be distinguished: target-oriented pursuit and various events in life influencing the career decision. These two have laid the foundation for 
professional identity. Target-oriented paths to a VET's career happened either straight from comprehensive school or after necessary work experience and vocational teacher education. Some teachers had found the career after working several years in their original vocation.

And in that point, during the secondary studies in basic education, I started to have this little dream that I did not dare to reveal to anyone; that I was a bit interested in this teacher's work.

Others had found the VET's career through coincident, such as friends and other close people implying that they would be excellent VETs. In most narratives, the participants did note that they had not consciously thought about a teacher's career in the first place. Some of them had worked as substitute teachers in vocational colleges. Positive teaching experiences and encouraging feedback during substitute periods made them apply for vocational teacher education.

... and then I was contacted and asked if I could think about teaching vocational subjects of my field... then I thought that when I have this opportunity and subjects or my own professional field, I though, yes, I will, and I was excited about that. (5)

My friends said that I would be pretty good at this kind of work. (7)

The development of professional identity in those who pursued in a VET's profession - Those who had determinedly wanted to become VETs had experiences ups and downs in their careers. Experienced events and coincident had made a crucial part of their development in a VET's profession (see also Huberman, 1989). The experiences of a fumbling start laid the grounds on professional identity (cf. also, DeWert, Babinski, \& Jones, 2003; Rodgers \& Scott, 2008; Uusiautti \& Määttä, 2013b).

These teachers considered their substance knowledge, and especially professional expertise and work-life skills, very strong already at the beginning of career. They had work experience from the field:

...when I was an entrepreneur, I employed so much vocational education students, and the student material was so bad that I was always thinking that why they have teachers there if they cannot teach even the basics (4)

At the beginning, they also had positive assumptions of their pedagogical skills based on their own learning experiences, for example, on the feedback given by their own teachers. Their pedagogical skills were seen strong also because they had a strong sense of high substance knowledge.

I had been dreaming of working as a teacher already for several years because somehow I was fascinated by guiding the youth taking workplace learning periods at my work (9)

And then at the training center, I had a teacher who was like tearing me apart. I thought that if I work as a teacher someday, I will never want my students to have those feelings (4)

Pedagogical ambition appeared first as the conscious identification in the teacher's profession. The participants were proud of having the VET's position and being able to educate skillful workers for the needs of work life.

At the beginning of my career, I was intoxicated by the ism of education. I was in a euphoric state because I was given the position and was able to work in a job I wanted to work. I was certain that my enthusiasm to learning and consequent joy would spread among all students in my class. My first year as a qualified teacher still supported this idealistic impression. (12)

Along with work years, the challenging nature of a VET's work became clear. The heterogeneous student groups and their manifold problems made many teachers doubt their pedagogical skills. Especially, 
Koski-Heikkinen, A., Määttä, K., \& Uusiautti, S.

teacher-student encounters and solution-oriented interaction skills as well as student guidance skills were seen insufficient (see also Kelchtermans, 1996; Lasky, 2005).

This work has become a social worker's job. This is not just a teacher's job, you do not just teacher the subject but you are a coach, mother, listener of heartache, guide of life... (4)

At the beginning of career, VETs' work-life skills and developmental abilities had been nascent because the work culture of a college differed substantially from the cultures in their previous workplaces. In addition, VETs need good administration skills (see also Köpsén, 2014).

...various evaluation systems, follow-up systems, support systems, personal study plans, and curricula (12)

Still, wish to participate in and influence the development of one's vocational field turned out to be a salient part of professional identity:

I wanted to participate in changing and developing work life, to cut down some old habits (9)

Successes in communal developmental work partly helped overcome uncertainty experienced at the beginning of a career. Likewise, the width of social network and importance of interaction, especially with colleagues and other professionals were considered extremely beneficial by the participants of this study (see also Mitchell, 1997).

The development of professional identity in VETs having started their careers by coincidence - Also these VETs had faced ups and downs in their career paths, especially at the beginning of careers. The participants remembered their insecurity at first, but also contentment with their career choice.

When younger, I did not find a teacher's work interesting at all, in other words, it was not my so-called dream profession. I was thinking about taking the job many times, but eventually I did.

These VETs had previously worked in the fields they started to teach, and therefore, they had a strong sense of substance knowledge. This encouraged them to seize the offer to become a VET. However, they assumed that the substance knowledge would be the basis of teaching and did not consider pedagogical skills relevant at the beginning of the career.

At first, I had been thinking that I have to bring up the themes. So, I sort of poured these theme on students and thought that I am the one who knows (5)

After familiarizing with the work environment, the VETs could pay more attention to the teaching, learning, and study processes. At the same time, they became concerned over their own pedagogical skills in teaching situations. They tried to secure the teaching situations by careful planning beforehand. This revealed the huge number of extra hours that is involved with the planning of lessons during one's free time. The concern over one's insufficient pedagogical skills and related work load caused fatigue and anxiety.

Those first years went by that I found it difficult to get up. I was already nervous about climbing those stairs up in that classroom and to create the teaching material (6)

Well, at first, I was afraid of and nervous about having the lessons. [I was thinking] if I could guide the students? (3)

The participants were balancing between their earlier professional identity formed during their previous career and the current, developing identity of a new VET. Indeed, pedagogical studies helped them to realize the areas of teachers' pedagogical skills and create an ideological foundation for their nascent professional identity (see also Kagan, 1992; Sachs, 2001). 
The birth and development of Vocational Education Teachers' (VET) professional identity

After teacher training, I learned to cut down theoretical teaching and increase practical teaching situations (11)

Work-life and developmental skills did not appear significant at the beginning of these VET careers, but as years went on, they became one of the reasons to stay in a VET's profession. These skills started to increase the sense of meaning in work. Probably, this is also due to their strong substance knowledge, analytic and active working styles, and versatile professional networks they had created already before their teaching careers.

When you work in a technological field, you always have plenty of challenges. Especially, in a small college, you have to be quite a magician to be able to teach several themes of the field. So, you have to study the mastery of various areas all the time. My purpose is to widen my knowledge of the various fields of technology. (11)

The research participants also described how colleagues' support and common discussions had encouraged them with the developmental work.

Those training sessions and then these colleagues around me. To me it means quite a lot that I have such good colleagues who I downright admire. (6)

\subsection{The Future of a VET's Professional Identity}

The strong substance knowledge obtained during one's previous career and the pedagogical skills provided from teacher training formed the cornerstones of the balanced development in a VET's career. When one had found the personal teaching style after the first years' fumble, the teachers' developmental and work-life skills started to develop as well.

So, it came to a point where I lost myself and my identity, and I felt like I could do nothing right. It was so horrible, and I already thought of cancelling and quitting. I kind of shed my identity skin. That's right. First, I took my old skin off and regrew it, but in the meanwhile, I had half a year, actually until Christmas, really hard time. (5)

As the professional identity started to mold, working became more meaningful. Likewise, the VETs started to cope better at work leaving more room to pedagogical development and developmental work. The clear professional identity also turned the impression of teacherhood into more realistic (see also Flores \& Day, 2006; Fuller \& Bown, 1975; Uusiautti \& Määttä, 2013b).

Experience makes you strong. Experience has made me into what I am today. Surely, pedagogical studies, colleagues, work environment, and all training, courses, lectures, as well as interaction with worklife and learning-at-work periods and practical skills tests, too. Work life is present all the time here. You have to be connected and know the development in your field. (5)

Yes, this had been a really challenging position to me. It has put me, I have been forced to put all for it, totally. (4)

The development of professional identity and future prospects were connected with personality development as well. To create a VET's identity, one had to give up the previous professional identity and related selfhood (cf., Cooper \& Clandinin, 1996). Accepting one's personality as a teacher, honesty and courage to reflect on teaching and oneself strengthened the professional identity and made one orientate toward the future of the teaching work (see also Urzua \& Vásquez, 2008).

I made plenty of mistakes. I tried to be a strict, assertive buddy, and this caused the conflicts with the adolescent students... The teacher's personality is what it is and you cannot mold it. Of course, you can act to a certain limit, but when you do it for years, you have to adjust to your personality... You have to be an honest personality. (7) 
Koski-Heikkinen, A., Määttä, K., \& Uusiautti, S.

It is really demanding and burdening. What especially puts strain is that you are on a razor edge and kind of hire-wire acting. It is not worth writing a detailed script at home in the evenings, but I live according to the situation. You should give to your personality. (6)

Active work attitude was seen to strengthen professional identity and wish to develop work-life and developmental skills. Not only one's own professional expertise, but also the development of students' professional identity was seen important. As the careers proceeded, VETs seemed to turn their attention from their subjective coping (see also Hong, 2010; Uusiautti \& Määttä, 2013a) to students' learning and support (see also Kagan, 1992).

When you have found your strength, when you reach a sort of top of the wall and when you have experience in the field and from many different enterprises. I would say that I could tell about the field so that students could construct their own professional identities in their own ways and that I could keep my word. And I do try to seize the situations. I do the same that I require of my students, so I do not stand back from the contact with clients. (5)

The participants were generally happy with their current work situation, and therefore, most of them did not have very high future expectations professional wise; their dreams did not diverge much from the daily VET's work (see also Veldman, van Tartwijk, Brekelmans, \& Wubbles, 2013).

But, well, I am so happy with today's situation that it is difficult to think about the future very profoundly. Although you plan your work beforehand, but when you feel good about it, it is difficult to think the future. (7)

All participants of this study surfaced clearly that their professional identities had developed greatly during their careers and that their identities still were developing. The professional identity was given birth by the experiences and insights from practical reality of the vocational college. Along with work years, the VETs had realized how wide-ranging professional skills and knowledge VETs need today and will need in the future. They emphasized especially the substance knowledge and active updating it in their own fields; and they even were concerned of the possibility of keeping sufficiently updated in the busy daily work at the vocational college.

\section{Conclusions}

\subsection{VET Identity}

The VETs in this study described their work in the light to two, often overlapping professional identities. These two professional identities can be called professional self and personal self (Day, Elliot, \& Kington, 2005; Day et al., 2006; Lasky, 2005; Lipka \& Brinthaupt, 1999; Ricoeur, 1992). Several researchers emphasize the connection between them: one cannot see oneself without mirroring to others (see Taylor, 1989). Personality and social environment are interconnected (Castells, 2004; Côte, 1996; Geijsel \& Meijers, 2005), but professional identity is also guided by instrumental and authorities' goals set at teacherhood stating when a teacher is qualified or expert (Jeans, 1996). According to the VETs, professional self consists of the professional identity through which one identifies oneself as a VET in general. Professional self-represented deeply-rooted impressions and expectations of a good VET's action, molded by the social environment. VETs try to behave and act in their teaching work according to their own experience-based interpretations about expectations set by society and their immediate environment.

I would like to be balanced, cooperative, and yet trendy VET to students and to the school community. (8)

Personal professional self appeared in the participants' narratives as selfhood identity including their inner, personal, and subjective professional self. Personal self, thus, represented their own personal understanding 
about themselves as VETs in all four aforementioned areas of professional identity. In addition, personal self-illustrated their ethical and value-based perspectives as well as their views about their own individual personalities.

....and at the beginning, I was shyer and more timid. Although I am like that still today, I have gained some sort of courage that others do not see but that gives me strength. (10)

\subsection{Multidimensional Professional Identity Develops Through Reflection}

Both professional and personal selves develop through reflection when a person reflects on his or her experiences. Understanding about oneself and professional identity are in constant development, change and renew (e.g., Volkmann \& Anderson, 1998). As reflection is crucial for the development of professional identity, the development of reflective skills should make a salient part of teachers' basic and in-service education (Antonek, McCormick, \& Donato, 1997; Roberts, 2000).

A VET's identity is complex and dynamic where the professional self-image and a teacher's various role try find mutual balance (Coldron \& Smith, 1999). In this sense, the professional identity includes a tension between one's teaching and the socially-produced teacher image. Cecilia Reynolds (1996) compares a teacher's work with a landscape that can be very demanding, persuasive, and restrictive. Today's VET's professional identity must cover also the national and international institutional and societal contexts because the functionality and efficiency of vocational education make one of the important foundations of societal development and economy (see e.g., Beauchamp \& Thomas, 2011).

Professional identity is multi-faced (Cooper \& Clandinin, 1996). Similarly, a VET's professional identity is influenced by historical, sociological, psychological, and cultural factors. Notwithstanding, professional identity includes many sub-identities that can be contradictory or, if in balance, strengthen the professional identity (McCarthey, 2001).

The process of constructing good professional identity is not necessarily easy or straightforward. Likewise, this study supported the earlier research results on how novice teachers experience "the reality shock" at the beginning of their careers (Flores \& Day, 2006; Uusiautti \& Määttä, 2013a, 2013b). The reality of the teachers' room does not correspond to the image gotten from teacher education, and the initial excitement can turn into isolation and lack of motivation, engagement, and work-satisfaction (Sachs, 2001), and even into a doubt of one's capability to work as a teacher (Rex \& Nelson, 2004).

Many kinds of feelings toward oneself and student belong to the development of a teacher's professional identity. The career development includes all states from satisfaction, joy, and contentment to vulnerability, insecurity, and anxiety (see also Jeffrey \& Woods, 1996; Kelchtermans, 1996; Thomas \& Beauchamp, 2011). Identity also means socialization into the roles, rules, expectations, and norms of the classroom, college, and wider society (Flores \& Day, 2006; Keichtermans \& Ballet, 2002; Uusiautti \& Määttä, 2013a, 2013b). As a sum, the development of a VET's professional identity can be viewed from four basic elements that can also be understood chronologically: (1) the important in oneself and for oneself; (2) important experiences during the earlier career; (3) important experiences during vocational teacher education; and (4) important experiences in the VET's profession.

\section{Discussion}

This study showed that vocational teacher education also meets new challenges, which do not just concern Finland but obviously many countries across the world. The level of VETs' expertise should be maintained internationally high, because vocational education has a very important role in every country's economic and industrial development. VETs' good basic skills also influence employees' wages and work satisfaction (see e.g., Agrawal, 2012; Min \& Tsang, 1990). Likewise, for example, China and Japan has raised their industry through 
Koski-Heikkinen, A., Määttä, K., \& Uusiautti, S.

various training programs (e.g., Cantor, 1985; Dougherty, 1990).

Naturally, country-specific differences occur, for example, in what kind of workforce is currently needed and thus influencing the purposes of vocational education (e.g., Margison, 1999). Dana (2001) highlighted the difference between industrialized countries and developing economies in Asia emphasizing that training programs must be relevant to the host environment (see also Minnis, 2000; Tilak, 2003). Green (1999) states that despite the current trend of internationalization, education must serve national economic and social goals. Likewise, Oketch (2007) summarizes the situation in Africa: "the key point is to transform [vocational education] so that what is offered can reflect the prevailing reality in the labour market" (p. 233).

The contribution of this study lies in the focus on vocational education teachers' development and provides viewpoints to their work and education universally. Teacher education should be developed both at basic and in-service training levels. Basic education must focus on vocational skills and the pedagogy of teaching them as well as interaction skills and abilities to encounter diverse students. How to be able to recognize and promote vocational education students' strengths and help them cope with the demands of future work life? VETs do not necessary receive support from people outside colleges, and therefore, colleagues' advice, helpful conversations, and cooperation become more and more important. These elements in VET's work should be invested in and advanced already during their basic education.

VET's in-service education is molded according to the changes in professions. Indeed, VETs need the latest work-life skills and knowledge. Still, the importance of personal identity and work engagement should not be underestimated even when the career has progressed. VETs have to stretch in many directions, but simultaneously they should be able to recognize successes in their work and appreciate the outcomes of their work. And it is noteworthy that even one positive feedback can be crucial to the professional development of some vocational education students.

None of the VETs participating in this study expressed that they would like to retire from the teaching position. International studies show that 14-50\% of teachers quit during their first five work years (DeWert et al., 2003; Quartz, 2003; Weiss, 1999). Reasons for giving up a teacher's career have been researched widely (Reynolds, Ross, \& Rakow, 2002; Smith \& Ingersoll, 2004). The decision is based on evaluations about oneself as a teacher, one's satisfaction at work and opportunities to succeed in teaching. Appreciation of the profession is important as well, and indeed, the attractiveness of vocational education has been a concern in many countries (e.g., Agrawall, 2013; Oketch, 2007; Pimpa \& Suwannapirom, 2008).

This study showed how VET's professional identity was strengthened along the career even if many of them had disappointments and failures at first. The findings give reason to develop teacher education so that VETs could prepare themselves for the problems occurring during the first years at work. At the same time, they should be equipped with abilities to cope with disappointments and insecurity in way that turns adversities into phases of development. Courage to talk about disappointments and unrealized dreams is a necessary skill that should be taught to VETs during basic education. Every teacher constructs his or her professional identity individually simultaneously developing his or her professional skills and personality. Therefore, personal strengths should be paid as much attention to as the practicing of professional skills and knowledge. 


\section{References}

Aalto, H.-K., Ahokas, I., \& Kuosa, T. (2008). All-round education and know-how in worklife 2030 - Keys to success in the future [In Finnish]. Turku: Tulevaisuuden tutkimuskeskus \& Turun kauppakorkeakoulu.

Akkerman, S. F., \& Meijer, P. C. (2011). A dialogical approach to conceptualizing teacher identity. Teaching and Teacher Education, 27(2), 308-319. http://dx.doi.org/10.1016/j.tate.2010.08.013

Agrawal, T. (2012). Vocational education and training in India: Challenges, status and labour market outcomes. Journal of Vocational Education \& Training, 64(4), 453-474. http://dx.doi.org/10.1080/13636820.2012.727851\#.U9H-XGfyWcw

Agrawal, T. (2013). Vocational education and training programs (VET): An Asian perspective. Asia-Pacific Journal of Cooperative Education, 14(1), 15-26.

Alam, G. M. (2008). The role of technical and vocational education in the national development of Bangladesh. Asia-Pacific Journal of Cooperative Education, 9(1), 25-44.

Antikainen, A. (2006). In search of the Nordic model in education. Scandinavian Journal of Educational Research, 50(3), 229-243. http://dx.doi.org/10.1080/00313830600743258

Antonek, J. L., McCormick, D. E., \& Donato, R. (1997). The student teacher portfolio as autobiography: Developing a professional identity. Modern Language Journal, 81(1), 15-27. http://dx.doi.org/10.1111/j.1540-4781.1997.tb01624.x

Bamberg, M. (Ed.) (2007). Narrative - State of art. Amsterdam: John Benjamins.

Bauman, Z. (1992). Soil, blood, and identity. Sociological Review, 40(4), 675-701. http://dx.doi.org/10.1111/j.1467-954X.1992.tb00407.x

Beauchamp, C., \& Thomas, L. (2009). Understanding teacher identity: An overview of issues in the literature and implications for teacher education. Cambridge Journal of Education, 39(2), 175-189. http://dx.doi.org/10.1080/03057640902902252

Beauchamp, C., \& Thomas, L. (2011). Understanding new teachers' professional identities through metaphor. Teaching and Teacher Education, 27(4), 762-769. http://dx.doi.org/10.1016/j.tate.2010.12.007

Beijaard, D., Meijer, P. C., \& Verloop, N. (2004). Reconsidering research on teachers' professional identity. Teaching and Teacher Education, 20(2), 107-128. http://dx.doi.org/10.1016/j.tate.2003.07.001

Bourdieu, P. (1980). Identity and representation [In French]. Actes de la recherche en sciences sociales, 35(1), 63-72.

Brubaker, R., \& Cooper, F. (2000). Beyond “identity”. Theory and Society, 29, 1-47.

Bruner, J. (1986). Actual minds, possible worlds. Cambridge: Harvard University Press.

Bruner, J. (1987). Life as narrative. Social Research, 54(1), 11-32.

Bullough, R. V. (2005). The quest for identity in teaching and teacher education. In G. Hoban (Ed.), The missing links in teacher education design: Developing a multi-linked conceptual framework (pp. 237-258). Dordrecht, NE: Springer.

Cantor, L. (1985). Vocational education and training: The Japanese approach. Comparative Education, 21(1), 67-75.

Chase, S. E. (2010). Learning to speak, learning to listen: How diversity works on campus. Ithaca, NY: Cornell University Press.

Clandinin, D. J. (Ed.) (2007). Handbook of narrative inquiry: Mapping a methodology. Thousand Oaks, CA: Sage.

Coldron, J., \& Smith, R. (1999). Active location in teachers' construction of their professional identities. Journal of Curriculum Studies, 31(6), 711-726. http://dx.doi.org/10.1080/002202799182954

Connelly F. M., \& Clandinin, D. J. (1999). Shaping a professional identity: Stories of educational practice. London: The Althouse Press.

Cooper, M. R., \& Clandinin, D. J. (1996). The multiple "I"s of teacher identity. In M. Kompf (Ed.), Changing research and practice: Teachers' professionalism, identities and knowledge (pp. 78-89). London: The 
Koski-Heikkinen, A., Määttä, K., \& Uusiautti, S.

Falmer Press.

Côte, J. E. (1996). Sociological perspectives on identity formation: The culture-identity link and identity capital. Journal of Adolescence, 19(5), 417-428.

Dana, L. P. (2001). The education and training of entrepreneurs in Asia. Education + Training, 43(8-9), 405-415.

Day, C., Elliot, A., \& Kington, A. (2005). Reform, standards and teacher identity: Challenges of sustaining commitment. Teaching and Teacher Education, 21(5), 563-577.

Day, C., Kington, A., Stobart, G., \& Sammons, P. (2006). The personal and professional selves of teachers: Stable and unstable identities. British Educational Research Journal, 32(4), 601-616. http://dx.doi.org/10.1080/01411920600775316

DeWert, M. H., Babinski, L. M., \& Jones, B. D. (2003). Safe passages: Providing online support to beginning teachers. Journal of Teacher Education, 54(4), 311-320. http://dx.doi.org/10.1177/0022487103255008

Dougherty, C. R. S. (1990). Unit costs and economies of scale in vocational and technical education: Evidence from the People's Republic of China. Economics of Education Review, 9(4), 389-394.

Erkkilä, R. (2005). A multi-voiced place - Teachers' narratives about life and schooling in Lapland [In Finnish]. Unpublished Doctoral dissertation, University of Oulu, Oulu, Finland.

Flores, M. A., \& Day, C. (2006). Contexts which shape and reshape new teachers' identities: A multi-perspective study. Teacher and Teacher Education, 22(2), 219-232. http://dx.doi.org/10.1016/j. tate.2005.09.002

Fuller, F. F., \& Bown, O. H. (1975). Becoming a teacher. In K. Ryan (Ed.), 74th Yearbook of the National society for the study of education (pp. 25-52). Chicago, IL: University of Chicago Press.

Gartner, W. (2007). Entrepreneurial narrative and a science of the imagination. Journal of Business Venturing, 22(5), 613-627. http://dx.doi.org/10.1016/j.jbusvent.2006.10.003

Geijsel, F., \& Meijers, F. (2005). Identity learning: The core process of educational change. Educational Studies, 31(4), 419-430. http://dx.doi.org/10.1080/03055690500237488

Giddens, A. (1991). Modernity and self-identity: Self and society in the late modern age. Cambridge: Polity Press.

Green, A. (1999). Education and globalization in Europe and East Asia: convergent and divergent trends. Journal of Education Policy, 14(1), 55-71. http://dx.doi.org/10.1080/026809399286495

Gubrium, J. F., \& Holstein, J. A. (2009). Analyzing narrative reality. Thousand Oaks, CA: Sage.

Habermas, J. (1991). Civic society and national identity: European reflections of the future [In German]. St. Gallen: Erker.

Hall, S. (1996). Introduction: Who needs identity? In S. Hall \& P. DuGay (Eds.), Questions of cultural identity (pp. 1-17). London: Sage.

Hatch, J. A., \& Wisniewski, R. (1995). Life history and narrative: Questions, issues, and exemplary works. In J. A. Hatch \& R. Wisniewski (Eds.), Life history and narrative (pp. 113-135). London: Falmer Press.

Hong, J. Y. (2010). Pre-service and beginning teachers' professional identity and its relation to dropping out of the profession. Teaching and Teacher Education, 26(8), 1530-1543. http://dx.doi.org/101016/j.tate.2010.06.003

Hoyle, E., \& John, P. D. (1995). Professional knowledge and professional practice. London: Cassell.

Huberman, M. A. (1989). The professional life cycle of teachers. Teachers College Record, 91(1), 31-57.

Inkson, K., \& Amundson, N. E. (2002). Career metaphors and their application in theory and counseling practice. Journal of Employment Counseling, 39(2), 98-108. http://dx.doi.org/10.1002/j.2161-1920.2002.tb00841.x

Jeans, B. A. (1996). The construction of professional identity. International Journal of Psychology, 31(3/4), 224-201.

Jeffrey, B., \& Woods, P. (1996). Feeling deprofessionalised. Cambridge Journal of Education, 26(3), 325-343. http://dx.doi.org/10.1080/0305764960260303

Kagan, D. M. (1992). Professional growth among pre-service and beginning teachers. Review of Educational Research, 62(2), 129-179. http://dx.doi.org/10.3102/00346543062002129

Kelchtermans, G. (1996). Teacher vulnerability: Understanding its moral and political roots. Cambridge Journal of Education, 26(3), 307-324. http://dx.doi.org/10.1080/0305764960260302 
The birth and development of Vocational Education Teachers' (VET) professional identity

Koski-Heikkinen, A. (2014). The vocational teacher's identity and authority: Vocational teachers and students searching for ideal teacherhood in vocational Education [In Finnish]. Doctoral dissertation, University of Lapland, Rovaniemi, Finland.

Köpsén, S. (2014). How vocational teachers describe their vocational teacher identity. Journal of Vocational Education \& Training, 66(29), 194-211. http://dx.doi.org/10.1080/13636820.2014.894554

Lasky, S. (2005). A sociocultural approach to understanding teacher identity, agency and professional vulnerability in a context of secondary school reform. Teaching and Teacher Education, 21(8), 899-916. http://dx.doi.org/10.1016/j.tate.2005.06.003

Leavy, A. M., McSorley F. A., \& Boté, L. A. (2007). An examination of what metaphor construction reveals about the evolution of pre-service teachers' beliefs about teaching and learning. Teaching and Teacher Education, 23(7), 1217-1233. http://dx.doi.org/10.1016/j.tate.2006.07.016

Lipka, R., \& Brinthaupt, T. (1999). Introduction: Balancing a personal and professional development of teachers. In R. Lipka \& T. Brinthaupt (Eds.), The role of self in teacher development (pp. 1-8). Albany, NY: New York State University Press.

Little, J. W., \& Bartlett, L. (2002). Career and commitment in the context of comprehensive school reform. Teachers and teaching: Theory and practice, 8(3), 345-354. http://dx.doi.org/10.1080/135406002100000486

Marginson, S. (1999). After globalization: Emerging politics of education. Journal of Education Policy, 14(1), 19-31. http://dx.doi.org/10.1080/026809399286477

McAdams, D. P., Josselson, R., \& Lieblich, A. (Eds.) (2006). Identity and story: Creating self in narrative. Washington, DC: American Psychological Association.

McCarthey, S. J. (2001). Identity construction in elementary readers and writer. Reading Research Quarterly, 36(2), 122-151.

McDiarmid, G. W., \& Clevenger-Bright, M. (2008). Rethinking teacher capacity. In M. CochranSmith, S. Feiman-Nemser, D. J. McIntyre, \& K. E. Demers (Eds.), Handbook of research on teacher education: Enduring questions and changing contexts (pp. 134-156). New York, NY: Routledge.

Min, W. F., \& Tsang, M. C. (1990). Vocational education and productivity: A case study of the Beijing General Auto Industry Company. Economics of Education Review, 9(4), 351-364.

Ministry of Education and Culture. (2010). Final report from the workgroup investigating vocational education teachers' and rectors' qualification requirements [In Finnish]. Helsinki: Ministry of Education and Culture. Retrieved from: http://www.minedu.fi/export/sites/default/OPM/Julkaisut/2010/liitteet/tr05.pdf?lang=fi

Minnis, J. R. (2000). Caught between tradition and modernity: Technical-vocational education in Brunei Darussalam. International Journal of Educational Development, 20, 247-259.

Mitchell, A. (1997). Teacher identity: A key to increased collaboration. Action in Teacher Education, 19(3), 1-14.

Oketch, M. O. (2007). To vocationalise or not to vocationalise? Perspectives on current trends and issues in technical and vocational education and training (TVET) in Africa. International Journal of Educational Development, 27, 220-234.

Pimpa, N., \& Suwannapirom, S. (2008). Thai students' choices of vocational education: Marketing factors and reference groups. Educational Research for Policy and Practice, 7(2), 99-107. http://dx.doi.org/10.1007/s10671-007-9035-9

Polkinghorne, D. E. (1995). Narrative configuration in qualitative analysis. In J. A. Hatch \& R. Wisniewski (Eds.), Life history and narrative (pp. 5-24). London: Falmer Press.

Quartz, K. H. (2003). “Too angry to leave”: Supporting new teachers' commitment to transform urban schools. Journal of Teacher Education, 54(2), 99-111. http://dx.doi.org/10.1177/0022487102250284

Reynolds, C. (1996). Cultural scripts for teachers: Identities and their relation to workplace landscapes. In M. Kompf (Ed.), Changing research and practice: Teachers' professionalism, identities and knowledge (pp. 69-77). London: The Falmer Press.

Reynolds, S. M., Ross, S. M., \& Rakow, J. H. (2002). Teacher retention, teaching effectiveness, and professional preparation: A comparison of professional development school and non-professional development 
Koski-Heikkinen, A., Määttä, K., \& Uusiautti, S.

school graduates. Teaching and Teacher Education, 18(3), 289-303. http://dx.doi.org/10.1016/S0742-051X(01)00070-1

Rex, L. A., \& Nelson, M. (2004). How teachers' professional identities position high-stakes test preparation in their classrooms. Teachers College Record, 106(6), 1288-1331

Ricoeur, P. (1992). Oneself as another. Chicago, IL: University of Chicago Press.

Ricoeur, P., \& Valdés, M. (1991). A Ricoeur reader: Reflection and imagination. Toronto: University of Toronto Press.

Riessman, K. C. (2008). Narrative methods for the human sciences. New York, NY: Sage.

Roberts, L. (2000). Shifting identities: An investigation into student and novice teachers' evolving professional identity. Journal of Education for Teaching, 26(2), 185-186. http://dx.doi.org/10.1080/02607470050127108

Rodgers, C. R., \& Scott, K. H. (2008). The development of the personal self and professional identity in learning to teach. In M. Cochran-Smith, S. Feiman-Nemser, D. J. McIntyre, \& K. E. Demers (Eds.), Handbook of research on teacher education: Enduring questions in changing contexts (pp. 732-755). New York, NY: Routledge.

Saarnivaara, M. (1998). Methodological and method solutions. Everyday life in research [In Finnish]. In M. Saarnivaara \& I. Sava (Eds.), We research. PhD students of art education talk about methodological issues [In Finnish] (pp. 185-201). Helsinki: TAIKK.

Sachs, J. (2001). Teacher professional identity: Competing discourses, competing outcomes. Journal of Education Policy, 16(2), 148-161. http://dx.doi.org/10.1080/02680930116819

Sfard, A., \& Prusak, A. (2005). Identity that makes difference: Substantial learnings closing the gap between actual and designated identities. Proceedings of the 29 th Conference of the International Group for the Psychology of Mathematics Education, 1(1), 37-52.

Shenton, A. K. (2004). Strategies for ensuring trustworthiness in qualitative research projects. Education for Information, 22, 63-75.

Smith, T. M., \& Ingersoll, R. M. (2004). What are effects of induction and mentoring on beginning teacher turnover? American Educational Research Journal, 41(3), 681-714. http://dx.doi.org/10.3102/00028312041003681

Somers, M. R. (1994). The narrative constitution of identity: A relational and network approach. Theory and society, 23(5), 605-649. http://dx.doi.org/10.1007/BF00992905

Spector-Mersel, G. (2011). Mechanisms of selection in claiming narrative identities: A model for interpreting narratives. Qualitative Inquiry, 17(2), 172-185. http://dx.doi.org/10.1177/1077800410393885

Taylor, C, (1989). Sources of the self: The making of the modern identity. Cambridge: Harvard University Press.

Tennant, M., \& Yates, L. (2005). Issues of identity and knowledge in the schooling of VET: A case study of lifelong learning. International Journal of Lifelong Education, 24(3), 213-225. http://dx.doi.org/10.1080/02601370500134909

Thomas, L., \& Beauchamp, C. (2011). Understanding new teachers' professional identities through metaphor. Teaching and Teacher Education, 27(4), 762-769. http://dx.doi.org/10.1016/j.tate.2010.12.007

Tilak, J. B. G. (2003). Vocational education and training in Asia. In J. P. Keeves, R. Watanabe, R. Maclean, P. D. Renshaw, C. N. Power, R. Baker, S. Gopinathan, H. W. Kam, Y. C. Cheng, \& A. C. Tuijnman (Eds.), International handbook of educational research in the Asia-Pacific Region (pp. 673-686). Dordrecht: Kluwer Academic Publishers. http://dx.doi.org/10.1007/978-94-017-3368-7_46

Trent, J. (2013). Becoming a teacher educator: The multiple boundary-crossing experiences of beginning teacher educators. Journal of Teacher Education, 64(3), 262-275. http://dx.doi.org/10.1177/0022487112471998

Urzua, A., \& Vasquez, C. (2008). Reflection and professional identity in teachers' future-oriented discourse. Teaching and Teacher Education, 24(7), 1935-1946. http://dx.doi.org/10.1016/j.tate.2008.04.008

Uusiautti, S. (2008). "Today, I'll work better than ever" Employees of the year describe their experiences of success at work [In Finnish]. Doctoral dissertation, University of Lapland, Rovaniemi, Finland.

Uusiautti, S., \& Määttä, K. (2013a). How to train good teachers in Finnish Universities? Student teachers' study process and teacher educators' role in it. European Journal of Educational Research, 1(4), 339-352. 
The birth and development of Vocational Education Teachers' (VET) professional identity

Uusiautti, S., \& Määttä, K. (2013b). Good teachers and good teacher educators: A glance at the current teacher education in Finland. Asian Journal of Education and e-Learning, 1(1), 1-16.

Veldman, I., van Tartwijk, J., Brekelmans, M., \& Wubbels, T. (2013). Job satisfaction and teacher-student relationships across the teaching career: Four case studies. Teaching and Teacher Education, 32(4), 55-65. http://dx.doi.org/10.1016/j.tate.2013.01.005

Volkmann M. J., \& Anderson, M. A. (1998). Creating professional identity: Dilemmas and metaphors of a first-year chemistry teacher. Science Education, 82(3), 293-310. http://dx.doi.org/10.1002/(SICI)1098-237X(199806)82:3<293::AID-SCE1>3.0.CO;2-7

Vähäsantanen, K. (2013). Vocational teachers' professional agency in the stream of change. Jyväskylä: Jyväskylä University Printing House.

Weiss, E. M. (1999). Perceived workplace conditions and first-year teachers' morale, career choice commitment, and planned retention: A secondary analysis. Teaching and Teacher Education, 15(8), 861-879. http://dx.doi.org/10.1016/S0742-051X(99)00040-2 
Koski-Heikkinen, A., Määttä, K., \& Uusiautti, S. 